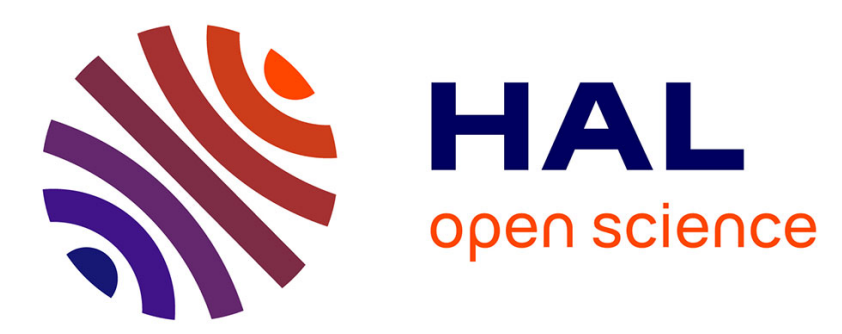

\title{
Restoration of reindeer lichen pastures after forest fire in northern Sweden: Seven years of results
}

Samuel Roturier, Sébastien Ollier, Lars-Evert Nutti, Urban Bergsten, Hans Winsa

\section{- To cite this version:}

Samuel Roturier, Sébastien Ollier, Lars-Evert Nutti, Urban Bergsten, Hans Winsa. Restoration of reindeer lichen pastures after forest fire in northern Sweden: Seven years of results. Ecological Engineering, 2017, 108, pp.143-151. 10.1016/j.ecoleng.2017.07.011 . hal-01615355

\section{HAL Id: hal-01615355 \\ https://hal.science/hal-01615355}

Submitted on 20 Jun 2018

HAL is a multi-disciplinary open access archive for the deposit and dissemination of scientific research documents, whether they are published or not. The documents may come from teaching and research institutions in France or abroad, or from public or private research centers.
L'archive ouverte pluridisciplinaire HAL, est destinée au dépôt et à la diffusion de documents scientifiques de niveau recherche, publiés ou non, émanant des établissements d'enseignement et de recherche français ou étrangers, des laboratoires publics ou privés. 
Restoration of reindeer lichen pastures after forest fire in northern Sweden: seven years of results

SAMUEL ROTURIER ${ }^{1}$, SÉBASTIEN OLLIER ${ }^{1}$, LARS-EVERT NUTTI $^{2}$, URBAN $^{2}$ BERGSTEN $^{3} \&$ HANS WINSA ${ }^{4}$

${ }^{1}$ Ecologie Systématique Evolution, Univ. Paris Sud, CNRS, AgroParisTech, Université ParisSaclay, F-91400, Orsay, France

${ }^{2}$ Sirges reindeer herding community, SE-96222 Jokkmokk, Sweden

${ }^{3}$ Faculty of Forest Sciences, Department of Biomaterials and Technology, Swedish

University of Agricultural Sciences, SE-90183 Umeå, Sweden

${ }^{4}$ Sveaskog, SE-95223 Kalix, Sweden

Corresponding author: Samuel Roturier, Laboratoire ESE, Université Paris Sud, rue du doyen André Guinier, B 360, 91405 Orsay cedex, tel. +331691556 70, email: samuel.roturier@upsud.fr 
ABSTRACT

Fire suppression since the $19^{\text {th }}$ century has modified the functioning of boreal forest ecosystems in northern Sweden. In the long run, it induces changes in understory vegetation that result, especially on mesic sites, in feather mosses and Ericaceous dwarf shrubs outcompeting ground lichens, thus decreasing winter pastures for reindeer husbandry. In 2008, a field experiment was established in which, two years after a large forest fire, reindeer lichen (Cladonia spp.) was transplanted across various plots. The general objective was to accelerate the recovery of lichen-rich reindeer pastures, and test the ability of lichen thalli to establish on burnt surfaces following different post-fire treatments (tree harvest and standing trees retained), in different transplantation seasons (summer and winter) and at different doses (0.45 L.m $\mathrm{m}^{-2}$ and $\left.2.25 \mathrm{~L} . \mathrm{m}^{-2}\right)$. The abundance and level of occupancy of viable and established lichen fragments was determined in $0.25 \mathrm{~m}^{2}$ quadrats in 2010, 2013 and 2015 . There was a continuous increase in lichen establishment over time, and seven years after transplantation, established lichen occupied, on average, $55 \%$ and $83 \%$ of the $0.25 \mathrm{~m}^{2}$ quadrats treated with the lower and higher doses, respectively. Nine years after fire, no lichen had colonized the control, i.e. the burnt surface outside the experimental area. At the site with standing trees retained, lichen had already formed a well-established mat with a significantly higher lichen occupancy and abundance than in the open, clear-cut sites, where lichen agglomerated in proto-mats. Lichen transplanted in late-summer exhibited higher abundance and occupancy than that transplanted in late-winter. On average, the difference in lichen occupancy and abundance between different doses after seven years was of lower magnitude than between the doses of lichen transplanted initially. The experiment reveals useful results for the restoration of reindeer pastures and for specifying fire management regimes adapted to both forestry and reindeer husbandry. 
Keywords: artificial dispersal; caribou; Cladonia; prescribed burning; restoration ecology; transplantation 


\section{INTRODUCTION}

In Fennoscandia, winter grazing grounds with abundant lichen cover in the boreal forest represent a critical resource for sustainable reindeer (Rangifer tarandus tarandus) husbandry mainly undertaken by indigenous Sami people (e.g. Heggberget et al. 2002). In Sweden, it was recently estimated that the area of lichen-rich forests has declined by $71 \%$ over the last 60 years (Sandström et al. 2016). The reasons for this decline might have several intertwined origins: climate change induced greening (Cornelissen et al. 2001), commercial forestry (Kivinen et al. 2010), intensive reindeer grazing (Akujärvi et al. 2014), and finally the reduction in burned forest area during the last 150 years due to fire suppression. In northern Sweden, fire suppression started around the end of the $19^{\text {th }}$ century as a result of prohibition of setting anthropogenic fires and, for the first time in history, efficient suppression of uncontrolled fire hazards to protect timber resources (Granström \& Niklasson 2008, see Östlund \& Roturier 2011 for a review of Tirén 1937). Although fire burns out reindeer lichen for several decades, today there is evidence that lichen-rich Pinus sylvestris forests in Fennoscandia originate from repeated fires. Historically the fire return interval in Swedish dry pine forests ranged between 20 and 100 years (Engelmark 1984, Zackrisson 1977), a much higher frequency than today, when expected return intervals are now hundreds of years (Niklasson \& Granström 2000, Wallenius 2011). In the prolonged absence of fire, altered below- and aboveground properties induce changes in understory vegetation that result, especially on mesic sites, in feather mosses and Ericaceous dwarf shrubs that can outcompete ground lichens (Nilsson \& Wardle 2005, Sulyma \& Coxson 2001).

The re-introduction of fire as a disturbance regime in Fennoscandian forests through restoration fire, prescribed burning prior to forest regeneration or wildfire, represents a straightforward option to ensure the restoration of suitable habitat for ground lichen in the 
long run, as it is for fire dependent species (Halme et al. 2013). However, the final successional phase in a plant community dominated by ground lichens is reached ca. 100 years after burning, mat-forming reindeer lichen species being dominant in the ultimate stages (Ahti \& Oksanen 1990, Morneau \& Payette 1989) depending on factors such as the fire severity or the distance from the dispersal source, even though burned areas may be used for reindeer foraging much earlier. In combination with fire, artificial dispersal of reindeer lichen could potentially contribute to much faster restoration and longer periods with lichen-rich pastures.

Reindeer lichens, a functional group including Cladonia stellaris, C. arbuscula, C. rangiferina and $C$. uncialis, mainly reproduce asexually and disperse by fragmentation of dry thalli, although there has been little quantification of the relative roles of sexual versus asexual propagation (Kotelko et al. 2008). Reproduction via fragmentation ensures that both symbionts are disseminated, but the colonization of the new habitats depends on the dispersal ability of the lichens (Esseen et al. 1981). For reindeer lichens, thallus fragments provide good short-distance dispersal but are inefficient for long-distance dispersal (Heinken 1999). As a transplantation method, artificial dispersal of lichen fragments offers the advantage of creating multiple propagules from a material that is fairly easy to collect and manipulate. Transplanting entire mats would require much more material and would result in a much more destructive impact at the source of collection. Based on published (Roturier \& Bergsten 2009, Roturier et al. 2007) and unpublished results from field experiments, transplantation of fragmented reindeer lichen seems to be the most appropriate method.

The success of transplanting reindeer lichen fragments after fire is akin to inverting the postfire chronosequence since propagules of reindeer lichens, traditionally considered to be late successional species, do not establish on newly burnt surfaces. This relates to the question of whether reindeer lichens are late successional species because they need a particular 
environment or substrate to establish and form a continuous mat, or because they are simply limited by their means of propagation, i.e. macroscopic propagules dispersed by wind and animals.

In this study, a field experiment was established in 2008 in which reindeer lichen fragments were artificially dispersed two years after a forest fire in boreal Sweden to investigate the restoration of reindeer lichen pastures. To our knowledge this was the first attempt to transplant reindeer lichen artificially in combination with fire at a large scale. The general hypothesis was that transplantation would significantly accelerate the recovery of the reindeer lichen mat on burnt forest soil. Our objective was to quantify the effects over time of transplantation season and amount (dose) of reindeer lichen in different stand environments produced by forest fire in order to accelerate the restoration of former lichen-rich ecosystems.

\section{MATERIAL AND METHODS}

\subsection{Study area}

The study area is located in Bodträskfors, Northern Sweden (66' $\left.{ }^{\prime} \mathrm{N}, 2^{\circ} 50^{\prime} \mathrm{E}\right)$ (Fig. 1a). Since 2000 the mean annual temperature has been $1.1^{\circ} \mathrm{C}$. The mean annual precipitation is about $553 \mathrm{~mm}$. On average, over a 20-years period, the annual snow cover has lasted between 175 and 200 days, usually forming in November and disappearing in May (SMHI 2015). The region is characterized by mid-north boreal vegetation with a tree layer dominated by Scots pine (Pinus sylvestris), with Norway spruce (Picea abies) occurring less frequently. The understory vegetation is mainly composed of Ericaceous dwarf-shrubs (Vaccinium vitis-idaea, V. myrtillus, Calluna vulgaris), feather mosses (Pleurozium schreberi, Hylocomium splendens) and lichens (Cladonia spp., Cetraria spp.). 
In August 2006 a forest fire, accidentally caused in very dry conditions, burnt about 1900 ha over the southern slope of the hill Stora Klusåberget (273 m a.s.1.). Due to extremely dry conditions, the fire was very severe at some locations, consuming all the soil organic material and leaving mineral soil exposed. Following the fire, burnt trees were clear-cut except on the top of the hill where the forest was left untouched to become a set-aside area with standing dead and viable trees. In other areas, depending on the landowner, the stands have been planted with pine seedlings or have been allowed to regenerate naturally.

Before the fire, the study area consisted of tree stands of different ages. At the experimental sites the forest was dominated by Scots pine (75-150 years-old). The field-layer vegetation was classified as Vaccinium vitis-idaea type on sandy moraine soils, and the bottom layer was dominated by feather mosses.

Before the fire, the area was used by local reindeer herding communities during late-summer. Since the fire, very few reindeer have been seen, scattered across the burnt area, some groups of male reindeer have been observed during summer seeking open areas to avoid insect harassment.
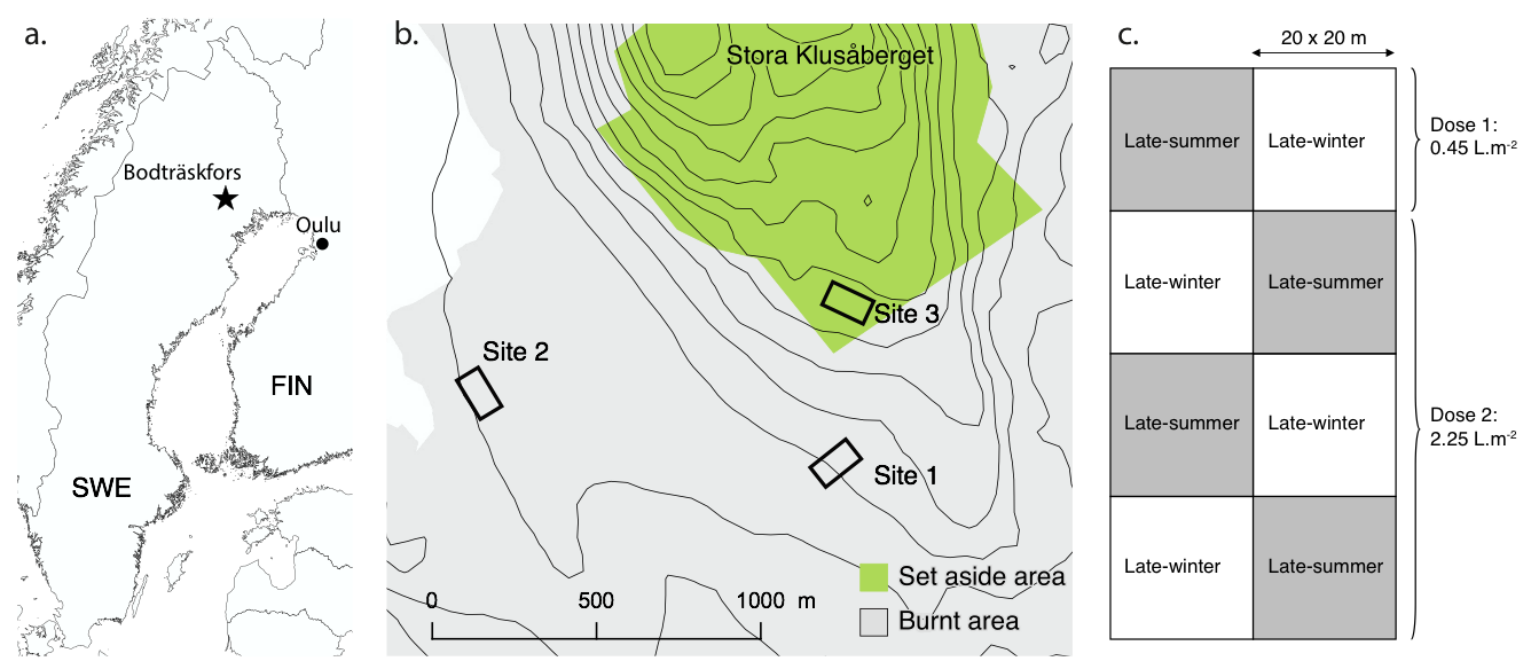
Figure 1. (a) Location of the study area, (b) study area and (c) transplantation design at site level.

2.2. Design and establishment of the experiment

The experiment was established in early September 2008 at three different sites within the burnt area (Fig. 1b), resulting in three different environments with respect to light exposure and burnt substrate (Table 1). Site 1 was located on the southern slope of Stora Klusåberget where the fire was the most severe. The understory vegetation had been totally removed by fire as well as the soil surface in many places and no vegetation had colonized the site at the time that the experiment was set up in 2008. The stand was clear-cut after the fire. Site 2 was located down the slope, adjacent to a moist-mesic area. The fire was of lower severity than at site 1 and some vegetation, such as feather mosses and dwarf shrubs, had survived. The stand was also clear-cut after the fire in August 2008 before the sowing of pine. Site 3 was located closer to the top of Stora Klusåberget within the set-aside area where the burnt tree stand was left to natural post-fire dynamics. At the time of establishment, canopy closure was estimated to be $38 \%$ at this site, according to a series of fisheye photos that were analysed using the software Gap Light Analyzer (Frazer et al. 1999). In comparison with other sites, the fire was of lower severity in this part of the study area, leaving some scattered trees alive and patches of thicker humus layer with understory vegetation. The $\mathrm{pH}$ of the topsoil was measured for five samples from each site (Table 1).

Eight plots $(20 \times 20 \mathrm{~m})$ were established in three blocks, one block at each site. In total 17.3 $\mathrm{m}^{3}$ of fragmented reindeer lichen were transplanted across the three sites during two different time periods: late-summer (September 2008) and late-winter (March 2009), i.e. on top of the snow cover. The artificial dispersal was performed manually with spades, covering the soil 
surface homogeneously. At each site, two different "doses" were applied: $180 \mathrm{~L}$ (about $5.5 \mathrm{~kg}$ $\mathrm{DM}$ ) in two plots corresponding to $0.45 \mathrm{~L} \cdot \mathrm{m}^{-2}$ (dose 1 hereafter), and a five-fold greater dose of $900 \mathrm{~L}$ (about $28 \mathrm{~kg} \mathrm{DM}$ ) in six plots corresponding to $2.25 \mathrm{~L} \cdot \mathrm{m}^{-2}$ (dose 2 hereafter), giving a total of 3 sites $* 2$ transplantation seasons * $(1$ plot with dose $1+3$ plots with dose 2$)=24$ plots (Fig. 1c).

Table 1. Characteristics of the three experimental sites at the time of lichen transplantation in 2008.

\begin{tabular}{|l|l|l|l|l|l|l|l|}
\hline Site & Altitude & Slope & Fire & Post-fire & Canopy & Topsoil & Soil type \\
& a.s.1. $)$ & & severity & treatment & cover (\%) & $\mathrm{pH}$ & \\
\hline 1 & 135 & 7 & High & Clear-cut, & 0 & & \\
\hline 2 & 128 & 0 & High/ & Clear-cut, & 0 & Mesic-dry \\
\hline 3 & 173 & 0 & Moderate & scarified, & & 5.5 & Mesic \\
& & & Sigh/ & Set-aside, & 38 & 5.6 & Mesic \\
\hline
\end{tabular}

\subsection{Lichen material and preparation}

The lichen material transplanted was collected from Oulu municipality, northern Finland (Fig. 1a), from an area that exports lichen. The lichen was stored in 60 L-plastic bags for a couple of days before the late-summer transplantation, and for five months outdoors without any 
particular treatment, in open plastic bags under cover, before the late-winter transplantation. The bags had been completely and homogeneously filled up with pieces of lichen mat along with some vegetation debris such as needles, pine cones, fragments of mosses etc. The composition of the lichen material was estimated visually: Cladonia stellaris (75\%), C. rangiferina $(12 \%)$, C. arbuscula $(7 \%)$ and Cetraria islandica $(6 \%)$.

In the days before transplantation, the lichen material was fragmented, using a vacuum shredder (STIHL ${ }^{\circledR}$ BG85). First the lichen was roughly divided into smaller pieces to be sucked up by the machine, and then a compost knife was used for the fragmentation, resulting in a mixture of lichen pieces from fragments a few millimetres long to cushions a few centimetres across.

\subsection{Inventory and measurements}

The experiment was inventoried three times following establishment: September 2010, August 2013 and September 2015. In each of the 24 plots, five $0.25 \mathrm{~m}^{2}$-permanent quadrats, or subplots, were used for monitoring. In addition, 10 quadrats were established outside each transplantation site as controls. Each subplot was subdivided into 100 grid squares of $5 \times 5$ cm to estimate: the viable lichen occupancy (colour-based criteria), the established lichen occupancy (fragments classified as viable with the presence of new shoots from the thallus and definitely attached to the substrate), moss occupancy, and vascular plant occupancy. The occupancy was measured as the number of grid squares (out of 100) occupied by at least one fragment.

The abundance of viable and established lichen fragments was estimated in 2013 and 2015 in 16 subplots randomly selected at each site. The exact number of viable and established fragments was measured in five grid squares $(5 \times 5 \mathrm{~cm})$, randomly selected out of 100 , in 8 
subplots treated with dose 1 and 8 with dose 2 . The subplots and the grid square numbers were recorded to monitor the dynamics over time.

\subsection{Statistical analysis}

Generalized Linear Mixed Models (GLMM) were used to test the effects of site, year since transplantation, transplantation dose and season and their interactions on abundance and occupancy of lichen (viable and established), moss and vascular plants. As the subplots were grouped by plot, nested within sites, we used a mixed modelling approach in order to take into account the hierarchical structure of the design. Random effects were incorporated into the model due to repeated measurements being taken from the same subplot over time. A binomial distribution was used for occupancy measures, where values ranged between 0 and 100. For abundance, we used a Poisson distribution. We tested the presence of potential residual spatial-autocorrelation with Moran's test by introducing spatial neighbours between subplots (de Espindola et al. 2011). No model presented any significant residual spatialautocorrelation. Finally, we performed multiple comparisons to compare occupancy and abundance between sites, and between doses when control subplots were included, accounting for the bias in p-values obtained. With the exceptions of moss and vascular plants, the occupancy and abundance always remained $<1$ in the control subplots. Consequently, we did not include control subplots in models of lichen data, but we used them for moss and vascular plants.

All the statistical analyses were conducted with R 3.4.0 software (R Core Team 2013) using "Ime4" (Bates et al. 2015), "smeans" (Lenth 2016), "spdep" (Bivand \& Piras 2015) and “spacetime” (Pebesma 2012) packages. 


\section{RESULTS}

\subsection{Occupancy of lichen fragments}

The occupancy of viable lichens fragments significantly increased over time at all sites and for all combinations of doses and seasons (Fig. 2). On average, viable fragments occupied $47 \%$ of the subplot area in $2010,72 \%$ in 2013 , and $78 \%$ in 2015 . In the control subplots, the occupancy always remained $<1 \%$ (results not shown). According to our model, the dose had a strong significant effect ( $\mathrm{p}$-value $<0.001$; see Appendix for the full analysis of deviance table): subplots treated with dose 1 had a consistently lower occupancy than those treated with dose 2 , on average, $19 \%$ and $57 \%$, respectively, in $2010,57 \%$ and $85 \%$, respectively, in 2015 . The sites also had a strong significant effect ( $p$-value $<0.001$ ): site 3 supported higher occupancy than sites 1 and 2, especially in 2010, one year after lichen transplantation. The difference between sites tended to decrease with time, especially for subplots treated with dose 2 (Fig. 2g-1), for which occupancy levelled out between 2013 and 2015. This was not the case for subplots treated with dose 1 (Fig. 2a-f), which kept increasing significantly (year*dose effect: $\mathrm{p}$-value $<0.001$ ). The season of transplantation also had a significant effect (p-value $<0.05$ ) on the occupancy of viable fragments. Subplots treated in late-summer always exhibited a higher occupancy compared to those treated in late-winter. 

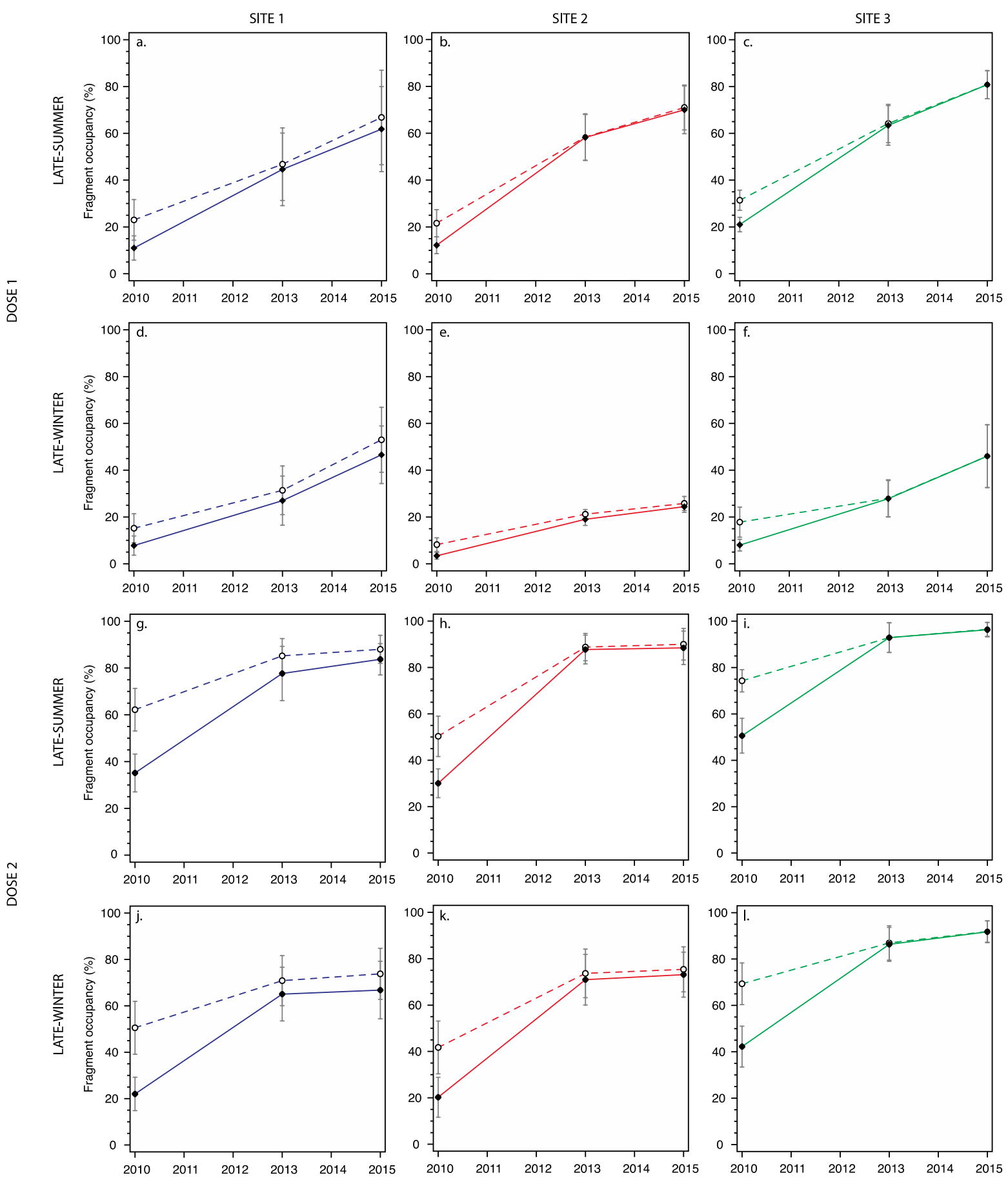

Figure 2. Mean ( \pm SD) occupancy of viable $(\mathbf{O}$, dotted lines $)$ and established $(\bullet$, solid lines $)$ lichen fragments between 2010 and 2015 at sites 1 (blue), 2 (red) and 3 (green) following transplantation at dose $1\left(0.45\right.$ L.m $\left.{ }^{-2}\right)(\mathrm{a}-\mathrm{f}, n=5)$ and dose $2\left(2.25 \mathrm{~L} . \mathrm{m}^{-2}\right)(\mathrm{g}-1, n=15)$ in different seasons. Dotted and solid lines show the trends between inventory dates for viable and established lichen, respectively. 
As for viable lichen fragments, the occupancy of established fragments significantly increased over time at all sites and for all combinations of doses and seasons (Fig. 2). On average, established fragments occupied $27 \%$ of the subplot area in $2010,69 \%$ in 2013 , and $75 \%$ in 2015. The dose, the site and the season of transplantation had strong significant effects on the occupancy of established fragments (p-values $<0.001$ ), following the same patterns as for viable fragments. Between 2010 and 2015, the occupancy of established fragments increased from $11 \%$ to $55 \%$ for dose 1 (Fig. $2 \mathrm{a}-\mathrm{f}$ ) and from $32 \%$ to $83 \%$ for dose 2 (Fig. $2 \mathrm{~g}-1$ ), on average. In the control subplots, it always remained $<1 \%$.

The occupancy ratio of established / viable fragments also exhibited strong significant differences between sites, years and seasons ( $\mathrm{p}$-values $<0.001)$. The dose had no significant effect and there was a significant site*year effect. In 2010, the ratio at site $3(0.62)$ was significantly higher than at site $1(0.48)$, but not than at site $2(0.50)$. In 2013 and onwards, the ratio ceased increasing, meaning that virtually all viable lichen that could possibly establish, had established. In 2015, the ratio at site 3 (0.99) was significantly higher than at site 2 (0.97), the ratio at site $1(0.91)$ being significantly lower than at the two other sites.

\subsection{Lichen fragment abundance}

The effects of the main factors on the abundance of both viable and established lichen fragments in the subplots were consistent with the lichen occupancy (Fig. 3, see Appendix). The abundance of both viable and established fragments was significantly higher at sites 3 compared to site 2 , mainly due to the significantly lower abundance of lichen dispersed at site 2, at dose 2 in late-winter (Fig. 3d). The fragment abundance was significantly higher in subplots treated with dose 2 than with dose 1 (p-values $<0.001)$, and exhibited a significant 
larger increase with dose 2 than with dose 1 (year*dose effect: p-values $<0.05$ ): in 2015 the average abundance of established fragments was 2.7 and 10.1 per grid square for doses 1 and 2 , respectively.
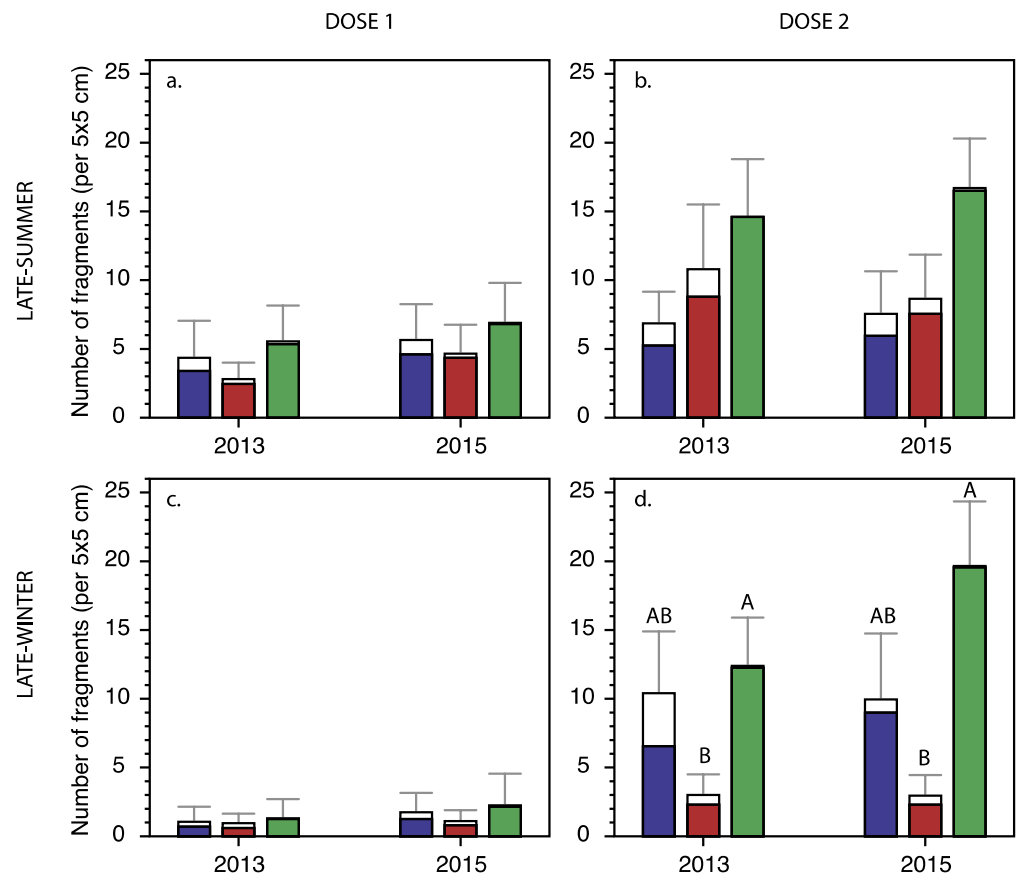

Figure 3. Mean ( $\pm \mathrm{SD}, n=20$ ) abundance of viable (white) and established (filled bars) lichen fragments (number per $5 \times 5 \mathrm{~cm}$-grid square) between 2013 and 2015 at sites 1 (blue), 2 (red) and 3 (green). Different capital letters indicate significant between-site differences (Tukey's test: $\mathrm{p}$-value $<0.05)$.

\subsection{Occupancy of mosses and vascular plants}

On average, mosses occupied $37 \%$ of the subplot area in $2010,64 \%$ in 2013 , and $70 \%$ in 2015, including the control subplots, exhibiting a significant increase over time. There was no significant difference between dose 1, dose 2 and the control (see Appendix). However, the occupancy of mosses increased significantly with time in subplots transplanted with dose 2 
compared to dose 1 and control subplots (year*dose effect: p-value $<0.01$ ). There was no significant difference between sites. In 2015 occupancy reached $65 \%$ at site 1 , mainly colonized by Polytrichum commune. Sites 2 and 3 reached $75 \%$ and $71 \%$ respectively, being mainly colonized by feather mosses (Pleurozium schreberi and Hylocomium splendens). The occupancy of vascular plants increased over time at all sites. There was a strong significant site effect (p-value $<0.001$ ), in 2015 reaching: $20 \%, 51 \%$ and $78 \%$ on average, at sites 1,2 and 3 , respectively.

\section{DISCUSSION}

4.1. Establishment of lichen fragments on burnt surfaces

The results of this experiment clearly showed that lichen fragments transplanted only two years after fire can survive on a burnt substrate and can establish, creating a new lichen mat within less than a decade. This was much faster than in natural conditions after forest fires, where fruticose reindeer lichen dominates the ground cover at intermediary stages of the succession by 50-100 years after fire (Ahti \& Oksanen 1990, Coxson \& Marsh 2001, Kumpula et al. 2000). It demonstrated empirically that reindeer lichens, especially Cladonia stellaris, generally considered to be a late successional species, can colonize harsh environments, but remain naturally limited by their propagation and dispersal, which rely on fragments of thalli (Nelson et al. 2015).

The establishment of a new lichen mat was particularly spectacular at site 3 , which exhibited a higher survival of lichen fragments two years after transplantation, with more homogeneous and abundant establishment of fragments compared to the other two sites. In spite of the 
competition with other taxa, mainly feather mosses and Ericaceous dwarf-shrubs, cushions several centimetres high had grown, forming a homogeneous mat over the whole experimental area (Fig. 4a). At the other two sites, lichen establishment consisted of wellestablished cushion-form thalli, agglomerating together with dead and living fragments, making a more heterogeneous proto-mat (Fig. 4b).

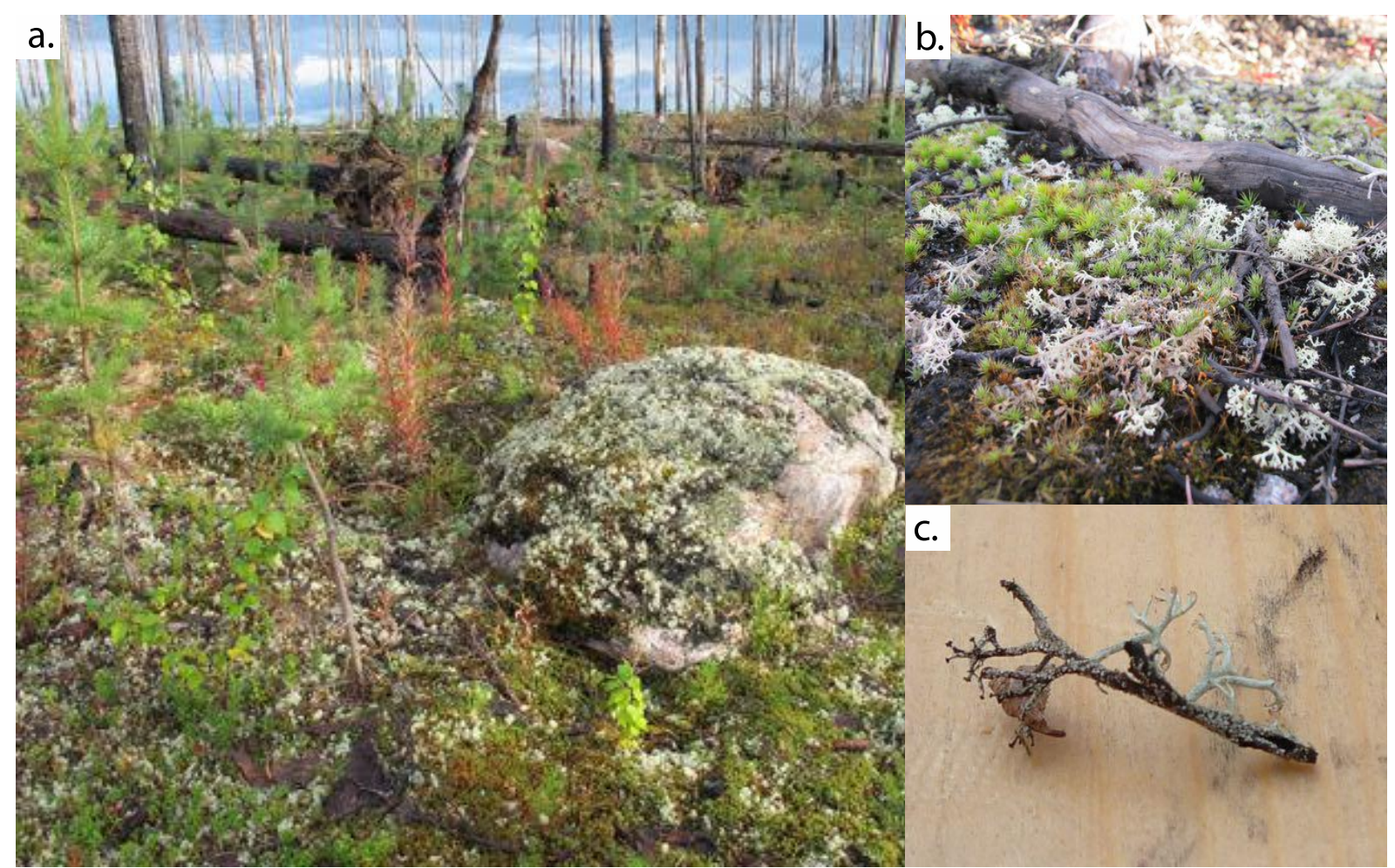

Figure 4. (a) Well-established lichen mat at site 3: lichen cushions several centimetres high in the set-aside area. (b) Proto-mat at site 1: established lichen fragments agglomerated with dead and living fragments, and with Polytrichum commune. (c) New podetia arising from a dead fragment at site 1 .

For poikilohydric organisms such as lichens, the growing period is correlated with their metabolically active periods, which are restricted to times when the thallus is wet (Palmqvist \& Sundberg 2000). Several studies have shown that relatively few parameters can be used to 
predict lichen growth effectively on a local scale, namely available light, atmospheric temperature and humidity (Gauslaa et al. 2007, Jonsson et al. 2008, Jonsson-Čabrajić et al. 2010), all of them being strongly regulated by the vegetation cover. Environments exposed to light and wind can provide reduced water availability for fragments (Gaio-Oliveira et al. 2004, Palmqvist et al. 2008).

In 2010, site 3 provided light conditions (38\% canopy closure, Table 1) within the range of optimum growth conditions for Cladonia stellaris according to Jonsson-Čabrajić et al. (2010). The uncut forest also constituted an efficient shield from the wind, thus facilitating lichen fragments becoming attached to the ground. Hyphae of the mycobiont must attach to the substrate by means of extracellular secretion (Hammer 1996), requiring a period of relative stability before exposure to strong winds. Heinken (1999) and Roturier et al. (2007) found that fragmented thalli had a high potential for being displaced by wind in open areas but not in more sheltered forest areas. In this experiment, the ratios of established / viable fragments quickly reached a maximum at site 3 , showing that virtually all viable fragments did attach themselves to the ground substrate.

Lichens transplanted across sites 1 and 2 were more exposed to desiccation through the combined effects of light and wind. The stability of fragments was also affected, as shown by the higher amount of still free, viable but loose fragments in 2015, indicating greater displacement of fragments (Fig. 3). These effects were probably even greater on the most severely burnt site 1 compared to site 2 . The lower cover of understory vegetation decreased the albedo, modifying the temperature regime at the soil surface (Certini 2005), and thus increased desiccation of fragments. The steeper slope and the soil being more severely burnt, increased runoff and decreased fragment stability. 
Higher moss occupancy could also have increased lichen stability locally as a result of their structure, as observed previously (Roturier et al. 2007), or by creating a microclimate that increases the duration of wet periods (Jonsson et al. 2008). It was not possible to demonstrate this effect with our set of data. Conversely, the significant year*dose effect on the occupancy of mosses, indicates that propagules of mosses were dispersed and established together with the lichen. This could have contributed to improving the overall lichen establishment. In summary, the set-aside area at site 3 provided the best conditions for lichen establishment with respect to light and substrate conditions. The open sites 1 and 2 provided poorer conditions, in particular the conditions at site 1, including the steeper slope and higher fire severity (Table 1).

\subsection{Lichen establishment and transplantation treatments}

The doses of lichen transplanted, as expected, had a strong influence on lichen abundance and lichen occupancy 7 years after transplantation. This is a key factor determining the efficiency and the feasibility of such restoration at a larger scale. Although lichen establishment was significantly higher in plots treated with dose 2 than dose 1 , the difference was never equivalent in magnitude to the initial inputs of lichen, i.e. five times greater (except at site 3

for plots treated in winter, see Fig. 3c-d). This indicates higher mortality of the lichen at dose 2, possibly induced by greater competition between individuals.

Summer transplantation clearly increased the survival and further establishment of lichen fragments, and thus the efficiency of the transplantation even at the lower dose. From this experiment, the effect of the season of transplantation could be the results of two factors. First, the storage of the lichen in non well-ventilated bags during the winter could have decreased the viability of lichen fragments prior to transplantation in March. This was not 
tested before transplantation and there is no previous study to refer to. Second, the lower temperature at the time of transplantation in March, still below $0^{\circ} \mathrm{C}$, could have decreased the viability of the lichen after transplantation (cf. Bjerke 2009).

However, based on our observations in the field, it should be noted that dead fragments could have contributed to the genesis of a new mat, where viable fragments could stabilize, agglomerate and establish. New thalli were also observed shooting from apparently dead fragments (Fig. 4c) as observed previously for reindeer lichens (Webb 1998) and terricolous bryophytes (Heinken \& Zippel 2004).

\subsection{Lessons for restoration}

From this experiment we are able to produce some recommendations with direct implications for forest management and reindeer husbandry. In the past, several papers reported the harvest of reindeer lichen, particularly in Finland, where it historically represents a "large" industry south of the reindeer herding area (3 000 tonnes per year of Cladonia stellaris were exported from Fennoscandia in the 1970s, see Kauppi 1979). Sami reindeer herders themselves have traditionally harvested reindeer lichen to feed their reindeer during bad grazing conditions. Although this is hardly controllable, the prevailing light conditions at the collection location of the lichen used for transplantation could have an effect on the growth of lichen in a more open environment (Palmqvist \& Sundberg 2000). The storage of lichen before transplantation is probably a critical factor since it determines the quality of the material transplanted. Traditional ecological knowledge and practices used by Sami reindeer herders should be considered: they traditionally store lichen in well-ventilated bags, which they freeze in dry conditions. Under such conditions lichens can easily survive the winter, and can even last some years (Honegger 2003). 
Transplantation of lichen onto burnt surfaces seems to be an appropriate option to accelerate the re-establishment of the reindeer lichen mat by introducing a substantial number of propagules after a fire. However, care should be taken with respect to the timing after fire. In this experiment, the lichen was transplanted two years after the fire and we believe that this is a reasonable time to wait to avoid higher $\mathrm{pH}$ following fire, pollution by ash particles, and to allow mosses and other vegetation to recolonize the soil, and provide a more favourable environment for lichens than bare, burnt ground.

The environmental conditions at the time of transplantation and during the first years after have a very strong effect on the results seven years later (see Table 1). The survival and establishment of lichens were significantly higher under tree cover compared to the open sites. Less severely burnt substrates also exhibited higher ratios of established / viable fragments. Lower fire severity is associated with structures that allow fragments to anchor themselves and to stabilize. In contrast, greater fire severity on drier sites, and an open site reduces the chance for lichen fragments to become anchored and grow. Late-summer transplantation seems to result in faster establishment than transplantation on top of the snow cover and may thus be preferable. It ensures shorter storage of the lichen, and it especially provides better light and air humidity conditions during the first months following transplantation. If large areas are to be restored, it might be advantageous to consider winter transplantation using snowmobile-mounted equipment, applying a higher dose of lichen to compensate for the lower establishment rates. At the higher dose, the difference in occupancy between seasons was only $12 \%$, on average.

The dose should be adapted to the environmental conditions, burning severity and the season of transplantation. As seen in this study, harsher site conditions could be effectively countered by higher doses of lichen. The dose should also be adapted to the costs and availability of the material to be transplanted. At the time that the experiment was established, the cost of lichen 
material at dose $1\left(0.45 \mathrm{~L} \cdot \mathrm{m}^{-2}\right)$ was $650 \mathrm{USD} \mathrm{ha}^{-1}$, and $3250 \mathrm{USD} \mathrm{ha}^{-1}$ at dose $2\left(2.25 \mathrm{~L} . \mathrm{m}^{-2}\right)$. Since lichen fragments were observed dispersing outside of the transplanted area, it may be cost effective to transplant lichens only to parts of the area to be restored. On burnt soil with a destroyed reindeer lichen mat this would probably result in significantly faster lichen restoration, for instance transplantation covering $30 \%$ of the area would correspond to a reasonable lichen cost ranging from 200 to $1000 \mathrm{USD} \mathrm{ha}^{-1}$.

\section{CONCLUSION}

The results from this field experiment demonstrate that transplantation of lichen can be successfully associated with prescribed burning or wildfire, restoring fire disturbance and accelerating lichen recovery. This could increase winter grazing areas, and reduce the lichenfree period after fire for reindeer in conifer forests with low lichen cover, while providing good forest regeneration in the meantime.

However, it is necessary to confirm these preliminary results and assess the sustainability of such restoration by: (i) studying the effects of growing vegetation on lichen during later successional stages of the post fire succession; (ii) assessing the full restoration of the lichen mat, and thus the time when reindeer grazing should be possible; and (iii) evaluating the possible synergy between reindeer husbandry and forestry associated with prescribed burning.

\section{REFERENCES}

Ahti, T., Oksanen, J., 1990. Epigeic lichen communities of taiga and tundra regions. Vegetatio 86, 39-70. 
Akujärvi, A., Hallikainen, V., Hyppönen, M., Mattila, E., Mikkola, K., Rautio, P., 2014. Effects of reindeer grazing and forestry on ground lichens in Finnish Lapland. Silva Fenn. 48, 1-18. doi:10.14214/sf.1153

Bates, D., Mächler, M., Bolker, B., Walker, S., 2015. Fitting Linear Mixed-Effects Models Using lme4. J. Stat. Softw. 67. doi:10.18637/jss.v067.i01

Bivand, R., Piras, G., 2015. Comparing Implementations of Estimation Methods for Spatial Econometrics. J. Stat. Softw. 63, 1-36. doi:10.18637/jss.v063.i18

Bjerke, J.W., 2009. Ice encapsulation protects rather than disturbs the freezing lichen. Plant Biol. 11, 227-235. doi:10.1111/j.1438-8677.2008.00113.x

Certini, G., 2005. Effects of fire on properties of forest soils: a review. Oecologia 143, 1-10. doi:10.1007/s00442-004-1788-8

Cornelissen, J.H.C., Callaghan, T. V, Alatalo, J.M., Michelsen, A., Graglia, E., Hartley, A.E., Hik, D.S., Hobbie, S.E., Press, M.C., Robinson, C.H., Henry, G.H.R., Shaver, G.R., Phoenix, G.K., Gwynn Jones, D., Jonasson, S., Chapin, F.S., Molau, U., Neill, C., Lee, J.A., Melillo, J.M., Sveinbjörnsson, B., Aerts, R., 2001. Global change and arctic ecosystems: is lichen decline a function of increases in vascular plant biomass? J. Ecol. 89, 984-994. doi:10.1111/j.1365-2745.2001.00625.x

Coxson, D.S., Marsh, J., 2001. Lichen chronosequences (postfire and postharvest) in lodgepole pine (Pinus contorta) forests of northern interior British Columbia. Can. J. Bot. 79, 1449-1464. doi:10.1139/b01-127

de Espindola, G. M., Pebesma, E., Câmara, G., 2011. Spatio-temporal regression models for deforestation in the Brazilian Amazon. STDM 2011, The International Symposium on Spatial-Temporal Analysis and Data Mining, University College London, 18th-20th July 2011. 
Engelmark, O., 1984. Forest fires in the Muddus National Park (northern Sweden) during the past 600 years. Can. J. Bot. 62, 893-898. doi:10.1139/b84-127

Esseen, P.-A., Ericson, L., Lindström, H., Zackrisson, O., 1981. Occurrence and ecology of Usnea Longissima in central Sweden. Lichenol. 13, 177-190. doi:10.1017/S0024282981000224

Frazer, G.W., Canham, C.D., Lertzman, K.P., 1999. Gap Light Analyzer (GLA), Version 2.0 [Computer software]. Simon Fraser University, Burnaby, British Columbia, \& the Institute of Ecosystem Studies, Millbrook, New York.

Gaio-Oliveira, G., Moen, J., Danell, Ö., Palmqvist, K., 2006. Effect of simulated reindeer grazing on the re-growth capacity of mat-forming lichens. Basic Appl. Ecol. 7, 109-121. doi:10.1016/j.baae.2005.05.007

Gauslaa, Y., Palmqvist, K., Solhaug, K.A., Holien, H., Hilmo, O., Nybakken, L., Myhre, L.C., Ohlson, M., 2007. Growth of epiphytic old forest lichens across climatic and successional gradients. Can. J. For. Res. 37, 1832-1845. doi:10.1139/X07-048

Granström, A., Niklasson, M., 2008. Potentials and limitations for human control over historic fire regimes in the boreal forest. Philos. Trans. R. Soc. B Biol. Sci. 363, 23532358. doi:10.1098/rstb.2007.2205

Halme, P., Allen, K.A., Auniņ̌s, A., Bradshaw, R.H.W., Brūmelis, G., Čada, V., Clear, J.L., Eriksson, A.-M., Hannon, G., Hyvärinen, E., Ikauniece, S., Iršènaitė, R., Jonsson, B.G., Junninen, K., Kareksela, S., Komonen, A., Kotiaho, J.S., Kouki, J., Kuuluvainen, T., Mazziotta, A., Mönkkönen, M., Nyholm, K., Oldén, A., Shorohova, E., Strange, N., Toivanen, T., Vanha-Majamaa, I., Wallenius, T.H., Ylisirniö, A.-L., Zin, E., 2013. Challenges of ecological restoration: Lessons from forests in northern Europe. Biol. Conserv. 167, 248-256. doi:10.1016/j.biocon.2013.08.029 
Hammer, S., 1996. Prothallus Structure in Cladonia. Bryologist 99, 212-217. doi: $10.2307 / 3244551$

Heggberget, T.M., Gaare, E., Ball, J.P., 2002. Reindeer (Rangifer tarandus) and climate change: Importance of winter forage. Rangifer 22, 13-31. doi:10.7557/2.22.1.388

Heinken, T., 1999. Dispersal patterns of terricolous lichens by thallus fragments. Lichenol. 31, 603-612. doi:10.1006/lich.1999.0219

Heinken, T., Zippel, E., 2004. Natural re-colonization of experimental gaps by terricolous bryophytes in Central European pine forests. Nova Hedwigia. 79, 329-251. doi:10.1127/0029-5035/2004/0079-0329

Honegger, R., 2003. The Impact of Different Long-Term Storage Conditions on the Viability of Lichen-Forming Ascomycetes and their Green Algal Photobiont, Trebouxia spp. Plant Biol. 5, 324-330. doi:10.1055/s-2003-40794

Jonsson-Čabrajič, A. V, Moen, J., Palmqvist, K., 2010. Predicting growth of mat-forming lichens on a landscape scale - comparing models with different complexities. Ecography (Cop.). 33, 949-960. doi:10.1111/j.1600-0587.2009.06079.x

Jonsson, A. V, Moen, J., Palmqvist, K., 2008. Predicting lichen hydration using biophysical models. Oecologia 156, 259-273. doi:10.1007/s00442-008-0990-5

Kauppi, M., 1979. The Exploitation of Cladonia Stellaris in Finland. Lichenol. 11, 85-89. doi:10.1017/S0024282979000104

Kivinen, S., Moen, J., Berg, A., Eriksson, Å., 2010. Effects of modern forest management on winter grazing resources for reindeer in sweden. Ambio 39, 269-278. doi:10.1007/s13280-010-0044-1

Kotelko, R., Doering, M., Piercey-Normore, M.D., 2008. Species diversity and genetic variation of terrestrial lichens and bryophytes in a boreal jack pine forest of central Canada. Bryologist 111, 594-606. 
Kumpula, J., Colpaert, A., Nieminen, M., 2000. Condition, potential recovery rate, and productivity of lichen (Cladonia spp.) ranges in the Finnish reindeer management area. Arctic 53, 152-160.

Lenth, R. V, 2016. Least-Squares Means: The R Package lsmeans. J. Stat. Softw. 69. doi:10.18637/jss.v069.i01

Morneau, C., Payette, S., 1989. Postfire lichen-spruce woodland recovery at the limit of the boreal forest in northern Quebec. Can. J. Bot. 67, 2770-2782. doi:10.1139/b89-357

Nelson, P.R., McCune, B., Roland, C., Stehn, S., 2015. Non-parametric methods reveal nonlinear functional trait variation of lichens along environmental and fire age gradients. J. Veg. Sci. 26, 848-865. doi:10.1111/jvs.12286

Niklasson, M., Granstrom, A., 2000. Numbers and sizes of fires: long-term spatially explicit fire history in a Swedish boreal landscape. Ecology 81, 1484-1499. doi:10.2307/177301

Nilsson, M.-C., Wardle, D.A., 2005. Understory vegetation as a forest ecosystem driver: evidence from the northern Swedish boreal forest. Front. Ecol. Environ. 3, 421-428. doi:10.1890/1540-9295(2005)003[0421:UVAAFE]2.0.CO;2

Östlund, L., Roturier, S., 2011. Forestry historical studies in the province of Västerbotten, northern Sweden: a review of Lars Tirén (1937). Scand. J. For. Res. 26, 91-99. doi:10.1080/02827581.2011.517953

Palmqvist, K., Dahlman, L., Jonsson, A., Nash, T.H., 2008. The carbon economy of lichens, in: Nash Thomas H., I.I.I. (Ed.), Lichen Biology. Cambridge University Press, Cambridge, pp. 182-215. doi:10.1017/CBO9780511790478.011

Palmqvist, K., Sundberg, B., 2000. Light use efficiency of dry matter gain in five macrolichens: relative impact of microclimate conditions and species-specific traits. Plant. Cell Environ. 23, 1-14. doi:10.1046/j.1365-3040.2000.00529.x 
Pebesma, E., 2012. spacetime: Spatio-Temporal Data in R. J. Stat. Softw. 51, 1-30. doi:10.18637/jss.v051.i07

R Core Team, 2013. A language and environment for statistical computing. R Foundation for Statistical Computing.

Roturier, S., Bäcklund, S., Sundén, M., Bergsten, U., 2007. Influence of ground substrate on establishment of reindeer lichen after artificial dispersal. Silva Fenn. 41, 269-280. doi:10.14214/sf.296

Roturier, S., Bergsten, U., 2009. Establishment of Cladonia stellaris after artificial dispersal in an unfenced forest in northern Sweden. Rangifer 29, 39-49. doi:10.7557/2.29.1.208

Sandström, P., Cory, N., Svensson, J., Hedenås, H., Jougda, L., Borchert, N., 2016. On the decline of ground lichen forests in the Swedish boreal landscape: Implications for reindeer husbandry and sustainable forest management. Ambio 45, 415-429. doi:10.1007/s13280-015-0759-0

Sulyma, R., Coxson, D.S., 2001. Microsite displacement of terrestrial lichens by feather moss mats in late seral pine-lichen woodlands of north-central British Columbia. Bryologist $104,505-516$.

Tirén, L., 1937. Forestry historical studies in the Degerfors district of the province of Västerbotten. Meddelanden från Statens Skogsförsäksanstalt, 30(1-2), 67-322. (In Swedish with English abstract)

Wallenius, T. H., 2011. Major decline in fires in coniferous forests - reconstructing the phenomenon and seeking for the cause. Silva Fenn. 45, 139-155. doi:10.14214/sf.36

Webb, E.T., 1998. Survival, persistence, and regeneration of the reindeer lichens, Cladina stellaris, C. rangiferina, and C. mitis following clearcut logging and forest fire in northwestern Ontario. Rangifer 18, 41-47. doi:10.7557/2.18.5.1440 
Zackrisson, O., 1977. Influence of forest fires on the north Swedish boreal forest. Oikos 29, 22-32. doi:10.2307/3543289

[dataset] SMHI (Swedish Meteorological and Hydrological Institute), 2015. Meteorological observations. [http://opendata-download-metobs.smhi.se/explore/\#]

\section{ACKNOWLEDGMENTS}

We are grateful to the two landowners Sveaskog and Sten-Åke Elming; to members of the Sirges reindeer herding community, Staffan Mikaelsson and Sarah Cogos for help during the fieldwork; to two anonymous reviewers for their constructive comments; and to Sees-editing Ltd for correcting the written English. Photo credit: Boden municipality archives (for the photo of the fire in the graphical abstract). Financial support was provided by the Program for Interdisciplinary Research in Ecological Engineering INGECO - CNRS-CEMAGREF, SLU and Sveaskog. Additional funding was provided by the Agence Nationale de la Recherche funded program BRISK (ANR 12_SENV_0005). 


\section{APPENDIX}

APPENDIX. Analysis of deviance table for generalized linear mixed model (type II Wild Chi-squared tests were used for both binomial and

\section{Poisson fits).}

\begin{tabular}{|c|c|c|c|c|c|c|c|c|c|c|c|c|c|c|c|c|c|}
\hline & & \multicolumn{11}{|c|}{ Occupancy [GLMM, f = binomial] } & & \multicolumn{4}{|c|}{ Abundance [GLMM, $\mathrm{f}=$ Poisson] } \\
\hline & & \multicolumn{2}{|c|}{ Viable lichen } & \multicolumn{2}{|c|}{$\begin{array}{c}\text { Established } \\
\text { lichen }\end{array}$} & \multicolumn{2}{|c|}{$\begin{array}{c}\text { Established / } \\
\text { viable }\end{array}$} & & \multicolumn{2}{|c|}{ Moss } & \multicolumn{2}{|c|}{ Vascular plant } & & \multicolumn{2}{|c|}{ Viable lichen } & \multicolumn{2}{|c|}{$\begin{array}{c}\text { Established } \\
\text { lichen }\end{array}$} \\
\hline & df & $\chi^{2}$ & $p$ & $\chi^{2}$ & $p$ & $\chi^{2}$ & $p$ & df & $\chi^{2}$ & $p$ & $\chi^{2}$ & $p$ & df & $\chi^{2}$ & $p$ & $\chi^{2}$ & $p$ \\
\hline Site & 2 & 25 & $<0.001$ & 40 & $<0.001$ & 49 & $<0.001$ & 2 & 5 & 0.09 & 100 & $<0.001$ & 2 & 9 & 0.009 & 14 & $<0.001$ \\
\hline Year & 2 & 361 & $<0.001$ & 685 & $<0.001$ & 924 & $<0.001$ & 2 & 258 & $<0.001$ & 283 & $<0.001$ & 1 & 10 & 0.002 & 23 & $<0.001$ \\
\hline Dose & 1 & 120 & $<0.001$ & 81 & $<0.001$ & 2 & 0.37 & 2 & 6 & 0.06 & 3 & 0.28 & 1 & 53 & $<0.001$ & 40 & $<0.001$ \\
\hline Season & 1 & 5 & 0.02 & 21 & $<0.001$ & 18 & $<0.001$ & & & & & & 1 & 14 & $<0.001$ & 11 & $<0.001$ \\
\hline Site*Year & 4 & 24 & $<0.001$ & 24 & $<0.001$ & 46 & $<0.001$ & 4 & 39 & $<0.001$ & 26 & $<0.001$ & 2 & 6 & 0.05 & 2 & 0.30 \\
\hline Site*Dose & 2 & 1 & 0.50 & 0.5 & 0.79 & 1 & 0.72 & 4 & 6 & 0.16 & 3 & 0.54 & 2 & 3 & 0.24 & 3 & 0.18 \\
\hline Year*Dose & 2 & 23 & $<0.001$ & 31 & $<0.001$ & 2 & 0.66 & 4 & 14 & 0.006 & 18 & 0.001 & 1 & 6 & 0.017 & 6 & 0.012 \\
\hline Site*Season & 2 & 0.2 & 0.87 & 0.8 & 0.67 & 1 & 0.73 & & & & & & 2 & 3 & 0.25 & 3 & 0.19 \\
\hline Year*Season & 2 & 17 & $<0.001$ & 10 & 0.006 & 2 & 0.49 & & & & & & 1 & 1 & 0.24 & 5 & 0.03 \\
\hline Dose*Season & 1 & 2 & 0.17 & 2 & 0.22 & 0.0 & 0.96 & & & & & & 1 & 7 & 0.010 & 8 & 0.006 \\
\hline
\end{tabular}




\begin{tabular}{|l|r|l|l|l|l|l|l|l|l|l|l|l|l|l|l|l|l|l|}
\hline Site*Year*Dose & 4 & 10 & 0.04 & 7 & 0.16 & 1 & 0.89 & & & & & & 2 & 4 & 0.17 & 3 & 0.18 \\
\hline Site*Year*Season & 4 & 0.8 & 0.94 & 2 & 0.82 & 7 & 0.15 & & & & & & 2 & 2 & 0.33 & 1 & 0.49 \\
\hline Site*Dose*Season & 2 & 0.8 & 0.68 & 3 & 0.23 & 4 & 0.15 & & & & & & 2 & 3 & 0.23 & 1 & 0.53 \\
\hline Year*Dose*Season & 2 & 0.3 & 0.84 & 0.0 & 0.97 & 6 & 0.05 & & & & & & 1 & 0.0 & 0.98 & 0.0 & 0.82 \\
\hline Site*Year*Dose*Season & 4 & 1 & 0.84 & 2 & 0.80 & 0.3 & 0.99 & & & & & & 2 & 2 & 0.29 & 0.6 & 0.73 \\
\hline Residuals & 301 & & & & & & & 405 & & & & & 451 & & & & \\
\hline
\end{tabular}

